\title{
SEKOLAH UNGGULAN BERASRAMA MODEL SMU TARUNA NUSANTARA MAGELANG JAWA TENGAH
}

\author{
Evaluasi Proses Pendidikan dan Pembinaannya
}

Oleh:

Asep Sukendar dan FX Sudarsono

\begin{abstract}
Abstrak
Penelitian ini bertujuan untuk memperoleh data yang akurat dan objektif tentang pelaksanaan program pendidikan dan pembinaan siswa SMU Tanuna Nusantara Magelang sebagai salah satu sekolah unggulan di Indonesia, berdasarkan komponen pendidikan yang dimilikinya. Alasan dipilihnya SMU Tanuna Nusantara sebagai objek penelitian karena sekolah ini dianggap memiliki keunggulan di bidang input, saranaprasarana, lingkungan belajar, serta SMU berasrama penuh. Hasil penelitian ini dapat dimanfaatkan untuk dijadikan acuan bagi sekolah-sekolah sejenis yang memiliki wawasan kualitas sebagai tujuan utamanya.

Penelitian ini menggunakan metode penelitian kualitatif evaluasi melalui pendekatan fenomenologis yang sifatnya studi kasus.

Hasil yang diperoleh antara lain: rekrutmen calon siswa dan guru SMU Taruna Nusantara dilaksanakan sangat selektif dan berjenjang, menggunakan kurikulum yang dikembangkan, yaitu Kurikulum Depdiknas tahun 1994 yang disempurnakan dan Kurikulum Khusus, proses pendidikan dan evaluasi meliputi: aspek akademik, jasmani, dan kepribadian, manajerial kepala sekolah dalam membina hubungan kerja dengan para pamong dan siswa dilakukan melalui pola kekeluargaan, dan keberadaan SMU Taruna Nusantara dirasakan berdampak positif bagi masyarakat di sekitarnya.
\end{abstract}

Kata kunci: sekolah unggulan

\section{Pendahuluan}

Upaya peningkatan mutu pendidikan pada semua jenjang, jenis, dan jalur pendidikan di Indonesia sudah merupakan tuntutan yang tidak bisa ditawartawar lagi. Namun, program peningkatan mutu dan relevansi pendidikan sampai saat ini masih belum memberikan hasil yang menggembirakan. Sudah banyak cara dilakukan disertai dengan keterlibatan masyarakat untuk meningkatkan mutu pendidikan ini. Akan tetapi, semua upaya itu belum dapat memuaskan semua pihak karena hasil yang dicapai masih belum optimal.

Kurang optimalnya mutu lulusan pendidikan yang dihasilkan, terutama pada siswa yang mempunyai keunggulan dalam kemampuan, keterampilan, 
bakat, dan minat dapat disebabkab oleh beberapa hal. Salah satu di antaranya karena sistem pendidikan yang dilaksanakan di tingkat SMU masih mengacu pada usaha menciptakan keseimbangan antara pemerataan dan keadilan. Hal ini menyebabkan siswa yang memiliki keunggulan kemampuan, minat, dan bakatnya tersebut sering kurang mendapatkan layanan yang sesuai dengan kelebihan-kelebihan yang dimilikinya.

Di pihak lain, dengan dilaksanakannya strategi keseimbangan dan pemerataan ini, maka untuk memaksimalkan potensi yang dimiliki oleh siswa unggul dalam belajar hanya akan ditentukan oleh motivasinya dan lingkungan belajarnya. Karena tidak memperoleh pengalaman yang sesuai, anak berbakat dapat menjadi "underachiever" (yaitu berprestasi di bawah taraf kemampuan yang dimiliki) dalam pendidikan (Utami Munandar, 1999). Salah satu penyebabnya adalah lingkungan belajar yang kurang menantang kepada mereka untuk mewujudkan kemampuannya secara optimal (Depdikbud, 1993). Namun, disadari pula oleh pemerintah bahwa untuk menciptakan lingkungan belajar yang baik diperlukan biaya dan dana yang tidak sedikit.

Berdasarkan hal-hal tersebut di atas, selanjutnya pemerintah melalui Departemen Pendidikan dan Kebudayaan dengan dibantu pihak swasta, telah mengambil suatu kebijakan dalam menerapkan strategi yang khusus dalam menangani siswa berbakat, yaitu melalui pendidikan dan pembinaan di sekolah unggulan. Dengan demikian, sekolah-sekolah unggulan yang didirikan merupakan wadah yang dirancang secara khusus untuk mewadahi, mengembangkan, dan menyalurkan minat dan bakat siswa-siswa unggulan itu. Sebab apabila bakat-bakat unggul yang dimiliki siswa tersebut tidak tersalurkan dengan baik, dikhawatirkan akan diaktualisasikan pada hal-hal yang bersifat negatif.

SMU-SMU unggulan yang kini mulai bermunculan di Indonesia, di antaranya ada yang dilaksanakan secara berasrama penuh. Dengan sistem pendidikan berasrama penuh, memang banyak harapan masyarakat tercurah pada SMU unggulan ini, terutama kaitannya dengan prestasi dan pendidikan kedisiplinannya bila dibandingkan dengan SMU nonunggulan. Mengapa demikian? Dikatakan demikian karena masyarakat beranggapan bahwa beberapa unsur pendidikan pada SMU unggulan seperti sumber daya manusia, fasilitas sekolah, dan keterampilan manajerial sangat memungkinkan bagi pencapaian tujuan pendidikan meraih prestasi akademik dan kepribadian yang 
lebih baik daripada sekolah pada umumnya, meskipun di segi lain, terutama yang menyangkut pembiayaan berkecenderungan lebih mahal.

Mengingat SMU unggulan sangat menitikberatkan kualitas, maka konsekuensi lain yang harus dihadapi oleh sekolah unggulan adalah penyiapan tenaga kependidikan, khususnya guru yang juga harus berkualitas. Kenyataannya, untuk dapat memilih dan menentukan guru yang berkualitas ternyata bukan persoalan mudah. Berkualitas tidaknya seorang guru, selain ditentukan oleh tingkat pendidikan juga ditentukan oleh tingkat pengalamannya. Suyanto (2001) mengatakan bahwa kualitas guru sedikit banyak ditentukan oleh sumber daya yang ada saat rekrutmen. Menurutnya, peningkatan guru sulit dilakukan jika sistem dan kondisi di sekitarnya tidak dibenahi. Persoalan akan muncul apabila sebuah sekolah unggulan swasta ingin merekrut guru-guru yang sudah berpengalaman. Selama ini, proses pemindahan guru harus melalui birokrasi yang cukup kompleks, memerlukan waktu lama, dan membutuhkan biaya yang tidak sedikit. Jika tidak, hal itu berakibat harapan untuk mendapatkan tenaga kependidikan yang berkualitas agar dapat mendukung proses dan hasil belajar yang bermutu di SMU unggulan tidak akan tercapai.

Di bidang kurikulum, sampai pada saat ini SMU unggulan tetap menggunakan kurikulum yang berlaku secara nasional (Kurikulum 1994) sebagaimana halnya SMU pada umumnya. Namun, untuk memberikan nilai keunggulan SMU unggulan, Kurikulum SMU 1994 ini ditambah dan diperkaya dengan kekhasan yang efektif dan fungsional sesuai dengan misi dan visi sekolah masing-masing.

Demikian juga halnya dengan sarana dan prasarana yang memadai sebagai dukungan mutlak agar proses belajar-mengajar yang dilaksanakan dan ouput yang dihasilkan dapat mengandung keunggulan yang optimal. Pengadaan sarana dan prasarana ini tentu akan berkaitan langsung dengan kesiapan dana. Di dalam pelaksanaannya, banyak sekolah unggulan yang terbentur dengan pengadaan dana ini, terutama bagi sekolah-sekolah swasta yang dikelola oleh yayasan atau lembaga yang kurang kuat dalam bidang dana operasional sekolah.

Hal lain yang juga besar pengaruhnya terhadap kelangsungan operasional SMU unggulan adalah masalah manajemen, terutama peran kepala sekolah. Seorang kepala SMU unggulan memegang peranan yang cukup tinggi, terutama pada penentuan kebijakan yang ada hubungannya dengan kelancaran 


\section{Sekolah Unggulan Berasrama Model SMU Taruna Nusantara Magelang Jawa Tengah: Evaluasi Proses Pendidikan dan Pembinaannya}

proses belajar-mengajar, penentuan dan penetapan tenaga kependidikan (guru dan karyawan), penciptaan iklim belajar, pencarian dan pengadaan dana, serta penciptaan etos kerja di antara semua sumber daya manusia yang terlibat.

Berbagai permasalahan sebagaimana disebutkan di atas, sangat penting untuk dikaji dan diteliti, khususnya di SMU Taruna Nusantara Magelang, sebagai salah satu SMU unggulan yang bertaraf nasional. Hal ini dibuktikan dengan cara rekrutmen yang dilakukan SMU Taruna Nusantara dengan menerima input siswa lulusan SLTP yang berasal dari berbagai propinsi di Indonesia.

Proses belajar-mengajar mencakup aspek akademik, kepribadian, dan kesamaptaan jasmani yang dievaluasi secara seimbang untuk menentukan tingkat keberhasilan siswa. Sarana dan prasarana belajar yang tersedia cukup memadai, termasuk sistem berasrama penuh bagi siswa, pengurus sekolah, dan guru-gurunya.

Berdasarkan keunggulan-keunggulan prestasi tersebut, proses pendidikan dan pembinaan siswa di SMU Taruna Nusantara menarik untuk dievaluasi. Bentuk pelaksanaan proses itu, khususnya dalam hal komponen pendidikannya dapat dilihat berdasarkan pemanfaatan fungsi komponen-komponen tersebut. Dengan demikian, keunggulan yang telah dilaksanakan akan dapat dijadikan acuan bagi pengembangan sekolah lebih lanjut, terutama dalam pengembangan dan peningkatan prestasi akademik dan aspek kepribadian para siswanya.

\section{Tujuan Penelitian}

Penelitian ini bertujuan memperoleh data yang akurat dan objektif tentang pelaksanaan program pendidikan dan pembinaan siswa SMU Taruna Nusantara Magelang sebagai salah satu sekolah unggulan, berdasarkan komponen mikrosistem pendidikan. Adapun tujuan penelitian yang dimaksud meliputi:

(1) ingin mengetahui pelaksanaan pendidikan dan pembinaan yang dilaksanakan di SMU Taruna Nusantara sebagai salah satu sekolah unggulan, terutama yang berkaitan dengan input siswa, sistem seleksi, rekrutmen guru, proses belajar-mengajar, dan kualitas lulusan,

(2) ingin mengetahui strategi pengelolaan dan pemanfaatan sarana dan prasarana untuk menunjang terciptanya lingkungan belajar yang kondusif, 
serta pengadaan dana untuk kegiatan operasional sekolah unggulan SMU Taruna Nusantara.

\section{Metode Penelitian}

Penelitian ini menggunakan metode penelitian kualitatif evaluasi melalui pendekatan fenomenologis yang sifatnya studi kasus. Penelitian diarahkan pada studi kasus, karena fokus penelitiannya terletak pada fenomena kontemporer, yaitu masalah sekolah unggulan yang bersifat aktual di dalam konteks kehidupan nyata, yakni dunia pendidikan di Indonesia yang prospek masa depannya masih belum menggembirakan. Pengumpulan data penelitian ini memanfaatkan pengurus sekolah, guru (pamong), dan siswa sebagai instrumen, melalui pengamatan, wawancara, serta dokumentasi. Analisis data digunakan teknik analisis domain, taksonomi, dan komponensial. Analisis ini dilakukan bersamaan waktunya dengan pengumpulan data. Pemantapan keabsahan data yang diperoleh dilakukan dengan menggunakan teknik triangulasi.

\section{Hasil Penelitian dan Pembahasan}

SMU Taruna Nusantara Magelang yang didirikan pada tanggal 14 Juli 1990 merupakan sekolah yang berasrama penuh. Artinya, seluruh siswa dan guru-gurunya berada di dalam satu lingkungan sekolah. Dengan pola seperti ini, pemanfaatan waktu dan kegiatan belajar dapat dilakukan seoptimal mungkin. Apalagi sekolah ini dalam salah satu misi pendidikannya berorientasi pada kualitas.

Berbicara tentang kualitas, secara otomatis akan berbicara pula tentang efektivitas sekolah. Apabila sekolah mampu mepertahankan atau dapat menciptakan efektivitas kinerjanya, aspek kualitas baru dapat diwujudkan. Dengan demikian, efektivitas sekolah merupakan prasyarat bagi terciptanya sebuah sekolah yang berkualitas. Jika masyarakat memiliki pandangan bahwa sebuah sekolah seperti SMU Taruna Nusantara Magelang memiliki kualitas yang lebih baik dari pada SMU pada umumnya. hal itu sebenarnya terkait dengan tingkat efektivitas sekolah yang bersangkutan. Sekolah yang efektif menurut Mortimore (Suyanto, 1995) dirumuskan sebagai suatu sekolah yang mampu mengembangkan kemampuan para siswanya jauh lebih baik dari pada kemampuan awal pada waktu siswa itu baru masuk di sekolah tersebut. 
Dari definisi sebagaimana dikemukakan Mortimore itu memiliki implikasi bahwa: pertama, sekolah yang efektif bisa terjadi pada masukan siswa yang baik atau buruk. Artinya, tidak selamanya sekolah yang masukan siswanya baik selalu efektif, begitu pula sebaliknya. Kedua, tidak ada satu sekolah pun, termasuk yang paling efektif, dapat menjamin ada kemajuan belajar pada semua siswanya. Ketiga, efektivitas dan efesiensi bisa saling tumpang tindih, tetapi kedua terminologi itu tidak mencerminkan hal yang sama. Oleh karena itu, bisa jadi sebuah sekolah dalam keadaan efisien, tetapi sebenarnya sekolah itu tidak efektif.

SMU Taruna Nusantara menitikberatkan kualitas aspek masukan, proses, ataupun hasil, sehingga efektivitas proses pembelajaran di sekolah merupakan salah kondisi yang harus dicapai. Hal itu bisa dilihat antara lain dengan diberikannya wewenang penuh oleh kepala sekolah kepada para wakil kepala sekolah untuk ikut terlibat secara langsung dalam proses pembelajaran yang dilaksanakan sesuai dengan fungsinya masing-masing. Misalnya Wakil Kepala Sekolah Urusan Kurikulum yang bertanggung jawab penuh atas keberhasilan perolehan prestasi di bidang akademik. Dia harus memantau semua komponen yang mendukung proses pembelajaran setiap saat. Demikian pula Wakil Kepala Sekolah Urusan Kesiswaan dan Asrama, Dia bertanggung jawab atas pembinaan kepribadian dan jasmani siswa melalui pola pengasuhan dan pelatihan, termasuk kehidupan di asrama yang harus memperlihatkan suasana yang sehat, kreatif, dan dinamis. Di lain pihak, pamong (guru) yang bertugas di SMU Taruna Nusantara diberi kelulasaan dan peluang untuk bisa melibatkan diri dalam setiap kegiatan sekolah di luar proses pembelajaran di dalam kelas.

Mengenai kualitas masukan siswanya, sekolah ini setiap tahun merekrut sekitar 300 orang siswa baru dari $9.000-10.000$ pendaftar. Banyaknya jumlah pendaftar merupakan satu kewajaran, mengingat SMU Taruna Nusantara saat ini telah menjadi idaman para siswa lulusan SLTP atau yang sederajat dari seluruh Indonesia. Oleh karena itu, dengan membludaknya calon siswa tersebut pihak sekolah dapat melakukan penjaringan dengan sangat selektif untuk bisa memilih bibit-bibit unggul yang diharapkan melalui berbagai macam jenis tes masuk, seperti: tes akademik, tes psikologi, tes kreativitas, tes kesehatan, dan tes fisik atau jasmani, termasuk terpenuhinya persyaratan administrasi yang ditetapkan sekolah.

Proses belajar-mengajar yang dilaksanakan di SMU Taruna Nusantara pada prinsipnya mengacu pada Kurikulum 1994 yang disempurnakan, dengan 
beberapa pengembangan dan perluasannya, yang dalam pelaksanaannya selalu berpedoman pada standar kompetensi SMU unggulan sebagaimana telah ditentukan oleh Departemen Pendidikan Nasional. Standar kompetensi ini perlu diperhatikan agar kemajuan prestasi para siswa dapat dipantau secara baik. Menurut Djemari Mardapi (1999), standar kompetensi diartikan sebagai kemampuan minimal yang harus dapat dilakukan peserta didik sesuai dengan jenjang pendidikannya. Standar kompetensi peserta didik setelah lulus jenjang pendidikan tertentu dinyatakan dalam bentuk pernyataan tentang kemampuan yang harus dimiliki dalam mata pelajaran tertentu. Dari hasil pengamatan, ternyata SMU Taruna Nusantara telah melakukan proses pembelajaran dan pembinaan para siswanya mencapai atau bahkan melampaui standar kompetensi yang telah ditetapkan. Hal itu dapat dibuktikan melalui berbagai aktivitas belajar, misalnya: jumlah jam tatap muka di kelas yang ditambah, diterapkan sistem belajar terstruktur pada malam hari, memberikan kesempatan kepada siswa tertentu untuk berkonsultasi dengan guru pada waktu sore dan malam hari (biasanya dilakukan di rumah guru), serta memberikan peluang seluas-luasnya kepada para siswa untuk melakukan praktikum di laboratorium secara mandiri di luar kegiatan intrakurikuler. Bagi SMU Taruna Nusantara yang menitikberatkan kualitas pada aspek masukan, proses, maupun hasilnya, maka efektivitas dalam proses pembelajaran di sekolah merupakan salah kondisi yang harus dicapai. Hal itu bisa dilihat antara lain dengan diberikannya wewenang penuh oleh kepala sekolah kepada para wakil kepala sekolah untuk ikut terlibat secara langsung dalam proses pembelajaran yang dilaksanakan sesuai dengan fungsinya masing-masing. Misalnya Wakil Kepala Sekolah Urusan Kurikulum yang bertanggung jawab penuh atas keberhasilan perolehan prestasi di bidang akademik, harus memantau semua komponen yang mendukung proses pembelajaran setiap saat.

Sistem pembelajaran terpadu yang dilaksanakan di SMU Taruna Nusantara ternyata telah membantu siswa untuk menghasilkan prestasi yang baik di bidang akademik. Salah satu contohnya adalah dalam sepuluh tahun terakhir ini memperoleh NEM (Nilai Ebtanas Murni) rata-rata tertinggi untuk tingkat Provinsi Jawa Tengah. Di samping itu, keberhasilan prestasi para siswa juga ditunjukkan melalui keberhasilannya menjuarai berbagai lomba KIR (Karya Ilmiah Remaja), serta keikusertaannya dalam kegiatan olimpiade bidang fisika, kimia, dan biologi, baik di dalam maupun di luar negeri. 
Adapun pelaksanaan evaluasi untuk bidang akademik ini, selain dilakukan dalam bentuk ulangan harian (UH) yang terjadwal dan serempak untuk seluruh mata pelajaran, ulangan umum bersama (UUB) untuk setiap Cawu, Ebta dan Ebtanas, juga dilakukan secara lisan pada saat pelaksanaan ujian pendadaran.

Di bidang pembinaan kepribadian, SMU Taruna Nusantara telah menetapkan sebagai salah satu aspek yang harus dicapai, sejajar dengan pencapaian prestasi aspek akademik. Oleh karena itu, untuk memberi pedoman dan arah yang sistematis, dibuatlah Kurikulum Khusus yang isinya menyangkut berbagai hal tentang pembinaan kepribadian siswa, sekaligus bagaimana cara mengevaluasinya.

Pembinaan dan pengevaluasian bidang kepribadian ini pada dasarnya dilaksanakan selama siswa mengikuti proses pendidikan. Seluruh aktivitas siswa di kelas, di luar kelas, di graha, bahkan di luar kampus sekali pun merupakan komponen penilaian bidang kepribadian. Hal itu perlu dilakukan mengingat bidang kepribadian ini merupakan sesuatu yang intangible, sesuatu yang tidak mudah diukur. Namun secara formal hasil pembinaan dan evaluasi, secara resmi harus dinyatakan dalam bentuk hasil kualitatif, yang dilaporkan dan ditulis setiap caturwulan di dalam buku rapor. Untuk itu, dibuatlah beberapa sistem pembinaan dan evaluasi yang harus digunakan secara aktif, baik di kelas maupun di lapangan oleh beberapa orang penilai, antara lain:

1) observasi, yang dilakukan oleh wali kelas, wali graha, pamong pengajar pengasuh (guru), pamong BP/BK, pamong graha, dan pelatih secara terusmenerus dan langsung. Observasi tersebut menilai langsung penampilan para siswa dalam merespons berbagai situasi, tantangan, dan tugas,

2) dialog, yang dilakukan oleh wali kelas, wali graha, pamong pengajar pengasuh, pamong BP/BK, pamong graha, dan pelatih secara langsung dan akrab untuk menjajagi berbagai sikap para siswa terhadap berbagai kejadian, masalah-masalah, masa depan dirinya dan bangsanya,

3) angket, dan sosiometri yang dilakukan oleh sesama siswa dalam berbagai kelompok, yaitu kelas, seluruh kelas I, II, atau III (per angkatan), dan keseluruhan siswa. (LPTTN, 1996 b: 20)

Di bidang fisik atau jasmani, pelaksanaan pembinaan dan evaluasi sama dengan aspek-aspek lainnya, yaitu dilakukan setiap siswa melakukan aktivitas, dengan penekanan pada segi prosesnya. Namun, secara formal ada beberapa materi yang pembinaan dan pengevaluasiannya dilakukan sesuai jadwal 
pelajaran, seperti materi teori olahraga/kesehatan dan tes kesamaptaan jasmani. Sebagaimana bidang akademik dan kepribadian, bidang jasmani pun harus mencapai target sesuai tujuan pembelajaran yang dinyatakan hasil akhirnya dalam bentuk nilai kualitatif di rapor. Melalui pembinaan dan pengevaluasian yang cukup sistematis, ternyata kemampuan fisik atau jasmani para siswa telah memberikan dukungan positif terhadap prestasi aspek akademik dan kepribadian.

Melalui pembinaan siswa di ketiga aspek tersebut (akademik, kepribadian, dan jasmani), yang dilakukan- oleh SDM (pengurus sekolah, guru, dan karyawan) yang berkualitas, serta dengan memanfaatkan fasilitas yang tersedia secara efektif dan efisien maka keberhasilan pendidikan dan pembinaan siswa di SMU Taruna Nusantara telah memberikan dampak positif pada lingkungan di sekitarnya. Hal itu tampak dengan banyaknya pihak masyarakat yang datang berkunjung untuk melihat secara langsung proses pembelajaran yang dilaksanakan di sekolah ini. Selain itu, dalam pembinaan jiwa sosial dan kemasyarakatan para siswa, kegiatan-kegiatan sosial yang biasa dilakukan di lingkungan masyarakat desa di sekitar kampus juga telah mendapat respon yang sangat baik. Di antaranya sebagaimana terlihat pada Program Latihan Kemasyarakat Peduli Lingkungan (LKPL) dan Program Desa Binaan yang secara rutin dilaksanakan oleh pihak sekolah yang bekerja sama dengan pemerintah daerah setempat.

\section{Simpulan}

Berdasarkan data temuan, analisis, dan interpretasi pada pembahasannya sebelumnya, selanjutnya dibuat beberapa kesimpulan umum sebagai berikut:

1. SMU Taruna Nusantara sebagai salah satu lembaga pendidikan jenjang menengah umum dapat dianggap sebagai model pendidikan alternatif bagi dunia pendidikan di Indonesia. Pelaksanaan pendidikan dengan model SMU berasrama penuh telah memberikan peluang untuk mengembangkan tingkat profesionalisme semua komponen pendidikan yang ada di dalamnya. Melalui proses pembelajaran yang berorientasi pada kualitas, sekolah ini telah mampu memperbaiki sistem dan meningkatkan kualitas pendidikan tingkat SMU secara intern.

2. Rekrutmen calon siswa SMU Taruna Nusantara sebagai raw input dilaksanakan secara selektif agar mendapatkan calon-calon siswa yang unggul. Penyeleksian dilaksanakan secara berjenjang mulai tingkat 
kabupaten, propinsi, sampai dengan tingkat pusat, dengan menggunakan berbagai jenis tes. Secara umum jenis tes itu meliputi persyaratan administrasi, tes akademik, tes kesehatan, tes psiko dan kreativitas, tes kesamaptaan jasmani, dan wawancara. Dengan cara seperti itu. SMU Taruna Nusantara telah berhasil menjaring calon-calon siswa yang kualitasnya betul-betul unggul. Para siswa lulusan SLTP/M.Ts. yang diterima telah siap secara fisik dan mental untuk mengikuti pendidikan selama tiga tahun di sekolah dengan sistem berasrama penuh.

3. Untuk menangani para siswa unggul, SMU Taruna Nusantara telah menyeleksi para guru atau pamong yang juga unggul, baik di bidang akademis maupun nonakademis, dan kreatif. Para pamong yang mengajar di sekolah ini diambil dari berbagai kalangan, seperti instansi Depdiknas, Taman Siswa, TNI, dan masyarakat umum. Di samping persyaratan latar belakang minimal harus lulusan program S-1 dengan IP kumulatif baik, para pamong ini harus sudah memiliki pengalaman mengajar di bidangnya minimal lima tahun. Seperti halnya siswa, para pamong pun diseleksi secara ketat melalui berbagai tes yang dilaksanakan oleh LPTTN.

4. Proses belajar-mengajar yang dilaksanakan di SMU Taruna Nusantara diarahkan pada terwujudnya keselarasan dan keseimbangan antara pengembangan kreativitas dan disiplin, pengembangan kompetitif dan kerjasama, serta keseimbangan antara kemandirian dan kebersamaan. Metode pembelajaran yang bervariasi, komunikasi dengan siswa yang dilakukan terus-menerus, serta pemanfaatan berbagai improvisasi dan kreativitas guru dalam proses pembelajaran, ternyata telah memberikan pengaruh yang positif terhadap keberhasilan belajar para siswa.

5. Untuk mendukung proses pembelajaran yang dilaksanakan, SMU Taruna Nusantara telah menyediakan sarana-prasarana yang cukup lengkap. Berbagai fasilitas yang ada senantiasa dimanfaatkan secara efektif dan efisien oleh seluruh komponen yang terkait.

6. Proses belajar-mengajar dan pembinaan siswa yang dilaksanakan di SMU Taruna Nusantara menggunakan waktu yang disediakan. baik untuk kegiatan rutin terjadwal, terprogram, terproyek, kegiatan mandiri maupun bimbingan secara kelompok atau mandiri di rumah pamong. Regiatankegiatan tersebut biasanya dilaksanakan di kelas, laboratorium, perpustakaan. luar kelas atau saat mengikuti latihan lapangan di luar kampus. Kegiatan-kegiatan siswa yang telah direncanakan secara matang 
selalu dievaluasi untuk mendapatkan informasi atas kekurangan dan kelebihan-kelebihannya. Berdasarkan hasil evaluasi inilah sekolah melakukan perbaikan atau pengembangan program untuk kegiatan yang sama pada masa mendatang.

7. Peranan Kepala SMU Taruna Nusantara dalam mengelola sekolah ini sudah bekerja sesuai dengan fungsi dan tanggung jawabnya. Pemberian tugas dan wewenang kepada para wakil kepala sekolah tidak berarti lepas tangan terhadap tanggung jawabnya selaku pimpinan. Monitoring terhadap kinerja seluruh komponen kependidikan di sekolah ini terus dilakukan meskipun tidak setiap saat. Hubungan dalam rangka pembinaan kepada pamong dan para siswa dilakukan penuh rasa kekeluargaan dengan asas saling asah. asih, dan asuh.

8. Dampak positif atas kehadiran SMU Taruna Nusantara dirasakan tidak hanya bagi dunia pendidikan, tetapi juga bagi masyarakat pada umumnya. Sekolah ini sering dijadikan sumber informasi untuk mengetahui bagaimana cara melaksanakan proses pembelajaran yang berkualitas.

\section{Daftar Pustaka}

Departemen Pendidikan dan Kebudayaan, 1993. Sistem Penyelenggaraan Sekolah Unggul. Jakarta.

Djemari Mardapi, dkk., 1999. Standar Kompetensi Lulusan SD, SLTP, dan SMU. Laporan Penelitian. Yogyakarta: Kerjasama Pusat Pengujian Balitbang Dikbud dengan Universitas Negeri Yogyakarta.

LPTTN, 1996. Pembinaan dan Penilaian Kepribadian Siswa SMY Taruna Nusantara. Jakarta: Lembaga Perguruan Taman Taruna Nusantara.

Mortimore dalam Suyanto, 1995. Efektivitas dan Kualitas Sekolah. Makalah dalam sarasehan tentang upaya peningkatan mutu SMU dan penuntasan wajar 9 tahun. Yogyakarta: Lemlit IKI IP Yogyakarta.

Suyanto, 2001. Artikel di surat kabar.

Utami Minandar, 1999. Pengembangan kreativitas anak berbakat. Jakarta: Departemen Pendidikan dan Kebudayaan-Penerbit Rineka Cipta. 